\title{
Literature Review : Pengaruh Batuk Efektif Untuk Pengeluaran Sputum Pada Pasien Tuberculosis
}

\author{
Ida Fauziyah ${ }^{1 *}$, Nuniek Nizmah Fajriah ${ }^{2}$, Firman Faradisi ${ }^{3}$ \\ ${ }_{1,2,3}$ Program Studi Diploma Tiga Keperawatan, Fakultas Ilmu Kesehatan Universitas Muhammadiyah \\ Pekajangan Pekalongan, Indonesia \\ *email: idafauziyah008@gmail.com
}

\begin{abstract}
Tuberculosis (TB) is in infectious disease that attacks the lungs caused by the bacterium Mycobacterium tuberculosis. Tuberculosis patients usually have symptoms of a prolonged cough, from the cought it can cause shortness of breath in someone who experiences these symtoms because there are too many secretions that are difficult to expel, causing a forced expiration. Forced expiration is one of the non-pharmacological interventions carried out to expel secretions, increase lung expansion, mobilize secretions and prevent side effects of retention of secretions. The purpose of this study was to describe the effect of forced expiration for sputum extraction in tuberculosis patients. Used in this study was a literature review from a database that had been determined used the keywoard tuberculosis, forced expiration, and sputum extraction. Obtained after forced expiration was reduced in the number of secretions in the patient. This study is that forced expiration can effectively reduce the amount of secretions in the body of tuberculosis patients.
\end{abstract}

Keywoard: Forced expiration; Sputum extraction; Tuberculosis (Pulponary tuberculosis)

\begin{abstract}
Abstrak
Tuberculosis (TB) adalah salah satu penyakit infeksi yang menyerang bagian paru-paru disebabkan oleh bakteri mycrobacterium tuberculosis. Pendertia tuberculosis biasanya memiliki gejala batuk yang berkepanjangan, dari batuk tersebut dapat menyebabkan sesak nafas pada seseorang yang mengalami gejala tersebut karena terlalu banyak sekret yang susah untuk dikeluarkan sehingga menyebabkan batuk efektif. Batuk efektif adalah salah satu tindakan non farmakologi yang dilakukan untuk pengeluaran sekresi, meningkatkan ekspansi paru, memobilisasi sekret dan mencegah efek samping dari retensi sekresi. Dari karya tulis ilmiah adalah untuk mengetahui gambaran tentang pengaruh batuk efektif untuk pengeluaran sputum pada pasien tuberculosis. Metode yang dilakukan dalam penelitian adalah literature review dari database yang telah ditentukan dengan menggunakan kata kunci Tuberculosis, latihan batuk efektif, dan pengeluaran sputum. Hasil yang didapatkan setelah dilakukan tindakan latihan batuk efektif yaitu banyaknya sekret pada pasien mulai berkurang. Kesimpulan karya tulis ilmiah ini bahwa tindakan latihan batuk efektif dapat mengurangi jumlah sekresi yang ada pada tubuh pasien tuberculosis.
\end{abstract}

Kata kunci: Latihan batuk efektik; Pengeluaran Sputum; Tuberculosis ( TB Paru)

\section{Pendahuluan}

Tuberculosis (TB) merupakan penyakit yang disebabkan oleh bakteri mycrobacterium tuberculosis menular yang dapat menyababkan kematian angka tertinggi di dunia setelah penyakit AIDS/HIV [13]. Tuberculosis (TB) merupakan salah satu penyakit infeksi yang diakibatkan oleh bakteri mycobacterium tuberculosis dengan gelaja yang berbeda- beda atau bervariasi, terutama dapat sering menyerang pada bagian organ paru- paru (Anggraeni 2019). Secara global angka kasus kejadian Tuberculosis per 100.000 penduduk turun sekitar 


\section{Prosiding Seminar Nasional Kesehatan Lembaga Penelitian dan Pengabdian Masyarakat Universitas Muhammadiyah Pekajangan Pekalongan}

2\% setiap tahunnya. Ragional yang paling cepat mengalami penurunan kasus tuberculosis di tahun 2013- 2017 yaitu ragional WHO Eropa (mengalami penurunan 5\% setiap tahunnya) dan ragional WHO Afrika (mengalami penurunan 4\% pada seriap tahunnya). Pada tahun tersebut pernurunan kasus penyakit tuberculosis sangat signifikan (4- 8\% setiap tahunnya).

Alpin, et al [1]. dapat memperkirakan kejadian kasus penyakit Tuberculosis pada tahun 2017 sejumlah 842.000 atau 319 kasus per 100.000 penduduk sedangkan yang mengalami kasus TB- HIV sejumlah 36.000 kasus setiap tahun atau 14 per 100.000 penduduk. Sedangkan jumlah kematian Tuberculosis diperkirakan sejumlah 107.000 atau 40 per 100.000 penduduk, dan kematian yang disebabkan oleh TB-HIV sejumlah 9.400 kasus atau 3,6 per 100.000 penduduk. Dengan kejadian tersebut yaitu sejumlah 842.000 kasus setiap tahunnya dan notifikasi kasus tuberculosis sejumlah 569.899 kasus, maka masish ada sekitar $32 \%$ kasus tuberculosis yang belum terjangkau, atau belum terdeteksi penyakitnya maupun tidak terlaporkan. WHO memperkirakan pada tahun 2017 di Negara Insonesia ada jumlah kasus Tuberculosis sebesar 23.000 kasus MDR/RR. Pada tahun 2017 jumlah kasus Tuberculosis yang tercatat pada program sejumlah 442.000 kasus dimana dari jumlah kasis tersebut dapat diperkirakan ada 8.600- 15.000 jumlah kasus MDR/RR Tuberculosis. (diperkirakan 2,4\& dari jumlah kasus baru dan $13 \%$ dari pasien tuberculosis yang diobati sebelumnya), tetapi jumlah cakupan kasus tuberculosis yang telah diobati baru sekitar $27,36 \%[1]$.

Tuberculosis (TBC) biasanya memiliki gejala batuk yang berkepanjangan, dari batuk tersebut dapat menyebabkan sesak nafas pada seseorang yang mengalami gejala tersebut karena terlalu banyak sekret yang susah untuk dikeluarkan sehingga bisa menyebabkan batuk efektif. Setiawan, et al [16]. yaitu batuk efektif merupakan salah satu tindakan terapi non farmakologi yang efektif dilakukan untuk mengeluarkan sputum (sekret yang ada di dalam paru- paru) sehingga dapat menghambat saluran pernafasan atau kebutuhan oksigennya kurang terpenuhi. Batuk efektif adalah suatu tindakan yang dilalukan untuk pengeluaran sekresi yang ada pada tubuh manusia, yang bertujuan untuk meningkatkan ekspansi pada paru-paru, mobilitas sekresi, dan untuk mencegah dari efek samping retensi sekresi [7].

Ariyanto, et al [7]. indikasi dan kontra indikasi yang dilakukan untuk klien batuk efektif yaitu :

Indikasi latihan batuk efektif diantaranya yaitu klien yang mengalami Jalan nafas tidak efektif, Klien imobilisasi, dan klien Pre dan post operasi.

Kontraindikasi latihan batuk efektif diantaranya yaitu klien yang mengalami Gangguan kardiovaskuler : Hipertensi berat, aneurisma, gagal jantung, infrak miocard, klien yang mengalami peningkatan Tekanan Intra Kranial (TIK) gangguan fungsi otak, dank lien Emphysema karena dapat menyebabkan rupture dinding alveolar.

Standar operasional prosedur (SOP) latihan batuk efektif [10]. yaitu:

Fase pra interaksi

Yang dilakukan dalam fase pra interasksi latihan batuk efektif diantaranya yaitu: dengan mencuci tangan, memakai apd, dan menyiapkan alat.

Fase orientasi 


\section{Prosiding Seminar Nasional Kesehatan Lembaga Penelitian dan Pengabdian Masyarakat Universitas Muhammadiyah Pekajangan Pekalongan}

Yang dilakukan daalam fase orientasi latihan batuk efektif diantarnya yaitu: Memberi salam terapeutik, Menjelaskan tujuan dan prosedur yang akan diberikan, Menanyakan kesetujuan atau persiapan pasien.

Fase kerja

Yang harus dilakukan dalam fase kerja latihan batuk efektif yaitu: Menjaga privasi pasien, Mepersiapkan pasien, dan Memberikan posisi duduk nyaman pada pasien, Memasang perlak/alas dan bengkom diatas pangkuan pasien, Menganjurkan pasien agar meminum air hangat terlebih dahulu, Meminta pasien agar meletakkan satu tangan di dada dan tangan satunya di abdomen (perut), Melatih pasien untuk melakukan nafas perut yaitu dengan cara menarik nafas melalui hidung, tahan selama 3 detik, kemudian menghembuskan nafas melalui mulut, Meminta pasien untuk mengulangi kegiatas tersebut sebanyak 3 kali, Meminta pasien untuk melakukan nafas dalam sebanyak 2 kali, kemudian yang ke-3 inspirasi, tahan nafas dan batukkan ke dengan kuat/ kencang, Menampung lendir dalam pot sputum, Menutup pot sputum, Membersihkan mulut pasien dengan tisu, dan yang terakhir yaitu Merapikan pasien/ memposisikan pasien ke dalam posisi awal.

Fase terminasi

Yang dilakukan dalam fase terminasi latihan batuk efektif diantaranya yaitu: Merapikan alat, Mengevaluasi hasil tindakan, Berpamitan dengan klien, Mencuci tangan, dan Membuat catatan kegiatan dalam lembar catatan keperawatan.

Tujuan dalam penelitian yang dilakukan ini yaitu untuk Menggambarkan pengaruh batuk efektif yang dapat membantu mengeluarkan sputum pada pasien tuberculosis

\section{Metode}

penelitian ini menggunakan rancangan Literature Review. Literature review adalah metode penulisan ilmiah dengan menggunakan cara menganalisis, mengevaluasi dengan kritis dan sintesis pengetahuan yang relevan dengan masalah penelitian pada topik tertentu [9]. Dengan kriteria inkulusi dan eksklusi artikel sebagai berikut.

Kriteria inklusi:

Pasien tuberculosis pada kasus tuberculosis yang mengalami penumpukan secret, terbit dilaman jurnal resmi, dibuktikan dengan ISSN, desain penelitian quasi eksperimen dan deskriptif dengan pendekatan observasional, terbit 10 tahun terakhir, artikel full teks minimal terdiri dari abstrak, pendahuluan, metode, hasil, pembahasan, simpulan dan saran

Kriteria eksklusi:

Sampel penelitiannya berbeda karakteristiknya sehingga tidak bisa dilakukan analisa keseluruhan, pengkatagorian hasil uji tidak sama untuk ketiga artikel. Contoh pengetahuan pada salah satu artikel dikategorikan tinggi, sedang, rendah, sedangkan artikel yang lainnya dikategorikan tinggi dan rendah.

Metode pengumpulan data yang digunakan adalah dengan mencari 3 (tiga) jurnal penelitian melalui website google scholar dengan topik yang sama dengan kata kunci batuk efektif, pengeluaran sputum. Lalu menyeleksi dan dipaparkan struktur penulisan publikasi penelitian tersebut dan dilakukan analisis. 


\section{Prosiding Seminar Nasional Kesehatan Lembaga Penelitian dan Pengabdian Masyarakat Universitas Muhammadiyah Pekajangan Pekalongan}

\section{Hasil dan Pembahasan}

\section{Hasil}

Berdasarkan ketiga artikel hanya 1 (satu) artikel yang memaparkan karakteristik responden. Mardiono, et al [10]. hanya menjabarkan distribusi pernafasan sebelum dan sesudah melakukan latihan batuk efektif. Ridhania, et al [13]. menjabarkan usia, jenis kelamin, pendidikan, pekerjaan dan status hidrasi. Tahir, et al [16]. tidak memiliki karakteristik responden karena hanya menggunakan satu responden dengan metode deskriptif.

Tabel 3.1 Distribusi Frekuensi Responden berdasarkan usia, jenis kelamin, pendidikan dan pekerjaan.

\begin{tabular}{llll}
\hline Artikel & Karakteristik & Frekuensi & Prosentasi (\%) \\
\hline 2 & Usia & & \\
$(\mathrm{n}=24)$ & $20-<45$ tahun & 5 & 83,3 \\
& $\begin{array}{l}\text { 45- } \leq 60 \text { tahun } \\
\text { Jenis kelamin }\end{array}$ & 1 & 16,7 \\
& Laki- laki & 5 & 83,3 \\
& Perempuan & 1 & 16,7 \\
& Pendidikan & & \\
SD & 2 & 33,3 \\
& SMP & 0 & 0 \\
& SMA & 3 & 50,0 \\
& Perguruan tinggi & 1 & 16,7 \\
& Pekerjaan & & 83,3 \\
& Bekerja & 5 & 16,7 \\
& Tidak bekerja & 1 & \\
& & & 100
\end{tabular}

Hasil analisa dari tabel 3.1 diatas menunjukkan karakteristik berdasarkan variable usia yang paling banyak adalah 20- $<45$ tahun sejumlah $5(83,3 \%)$, variabel jenis kelamin paling banyak laki-laki sebanyak $5(83,3 \%)$, variabel berdasarkan pendidikan paling banyak SMA berjumlah $3(50,0)$, variable berdasarkan pekerjaan paling banyak yang bekerja berjumlah $5(83,3)$.

Tabel 3.2 Nilai rata-rata sebelum dan sesudah diberikan teknik batuk efektif

\begin{tabular}{llll}
\hline Nilai rata rata pengeluaran sputum & & \\
\hline Artikel & $\begin{array}{l}\text { Sebelum diberikan } \\
\text { teknik batuk efektif }\end{array}$ & $\begin{array}{l}\text { Sesudah diberikan } \\
\text { teknik batuk efektif }\end{array}$ & P. value \\
\hline $\begin{array}{l}\text { Artikel } 1 \\
\mathrm{n}=32\end{array}$ & 23,4 & 19,8 & 0,000 \\
$\begin{array}{l}\text { Artikel } 2 \\
\mathrm{~N}=6\end{array}$ & 1,67 & 1,00 & 0,010 \\
$\begin{array}{l}\text { Total } \\
\mathrm{n}=38\end{array}$ & 19,96 & 16,83 & $<0,05$ \\
\hline
\end{tabular}




\section{Prosiding Seminar Nasional Kesehatan Lembaga Penelitian dan Pengabdian Masyarakat Universitas Muhammadiyah Pekajangan Pekalongan}

Hasil dari tabel 3.2 menyebutkan bahwa artikel 1 sebelum dilakukan teknik batuk efektif rata- rata pengeluaran sputum yaitu 23,4 dan setelah dilakukan teknik batuk efektif menjadi 19,8 dengan $p$ value 0,000 . Artikel ke ke-2 nilai rata-rat pengeluaran sputum sebelum dilakukan teknik batuk 1,67 dan setelah dilakukan teknik batuk efektif menjadi 1,00 dengan $p$ value 0,010 . Hasil rat- rata pengeluaran sputum kedua artikel sebelum dilakukan teknik batuk efektif sejumlah 19,96 dan setelah dilakukan teknik batuk efektif menjadi 16,83 dengan $\mathrm{p}$ value menunjukkan $<0,05$. Hal ini menunjukkan bahwa ada pengaruh yang signifikan terhadap pengeluaran sebelum dan sesudah dilakukan teknik batuk efektif pada pasien tuberculosis.

\section{Pembahasan}

Pada penelitian tentang pengaruh batuk efektif untuk pengeluaran sputum pada pasien tuberculosis memang sangat berpengaruh, karena tindakan batuk efektif sangat efektif untuk pengeluaran sputum dan dapat membantu membersihkan secret pada jala nafas serta mampu mengatasi sesak nafas pada pasien TB paru [15]. Batuk efektif merupakan salah satu tindakan perawat untuk membersihkan sekresi jalan nafas, yang dapat berpengaruh untuk meningkatkan mobilitas sekresi dan mencegah resiko tinggi retensi sekresi. Setelah dilakukan tindakan keperawatan 1X24 jam diharapakan pasien TB paru dalam mengelami peningkatan bersihan jalan nafas [6].

Tahir, et al [16]. menyatakan bahwa tindakan batuk efektif dapat bertujuan untuk membebaskan jalan nafasa dari akumulasi sekret, mengeluarkan sputum untuk pemeriksaan diagnostik laboratat dan mengerangi sesak nafas akibat akumulasi sekret. Hasil penelitian menunjukkan bahwa setelah dilakukan tindakan batuk efektif suara nafas tambahan (ronchi) tidak terdengar lagi. Bunyi ronchi disebabkan karena aliran udara melalui saluran nafas telalu banyak sputum. Sputum pada jalan nafas dapat dimobilisasi keluar melalui tindakan batuk efektif [11].

Kemampuan mengeluarkan sekret pada pasien tuberculosis ditunjukkan pada hari pertama sampai hari terakhir pemeberian tindakan batuk efektif. Kemampuan mengeluarkan sekret berkaitan dengan kemampuan pasien melakukan batuk efektif. Batuk efektof dapat mendorong sekret yang menumpuk pada jalan nafas untuk keluar. Hal ini ditunjang dengan teori yang menyebutkan bahwa tindakan batuk efektif dapat membantu proses pengeluaran sekret yang menumpuk pada jalan nafas sehingga tidak ada perlengketan pada jalan nafas sehingga jalan nafas paten dan sesak nafas berkurang [2].

Mardiono, et al [10]. membuktikan bahwa latihan tindakan batuk efektif sangat efektif dalam pengeluaran sputum dan membantu membersihkan jalan nafas pada pasien TB paru di ruang rawat inap Rumah sakit Mardi Rahayu Kudusda didukung juga oleh penelitian Septherisa, et al [10]. yang membuktikan bahwa adanya efektifitas latihan batuk efektif dalam meningkatkan sekresi mucus pada panyakit TB paru, penyakit dalam dirumah sakit AK. Gani [10].

Dari pembahasan diatas dapat disimpulkan bahwa latihan batuk efeltof dapat direkomendasikan untuk tenaga kesehatan terutama perawat agar dapat di aplikasikan untuk mengurangi jumlah sputum pada pasien tuberculosis. Latihan batuk efektif di aplikasikan pada pasien karena tidak memiliki efek samping pada sakit yang dialami. 


\section{Prosiding Seminar Nasional Kesehatan Lembaga Penelitian dan Pengabdian Masyarakat Universitas Muhammadiyah Pekajangan Pekalongan}

\section{Kesimpulan}

Persamaan hasil penelitian adalah tindakan batuk efektif dapat mengeluarkan sputum pada pasien tuberculosis. Perbedaannya adalah hasil rata- rata frekuensi pernafasan setelah dilakukan tindakan batuk efektif. Pada penelian pertama yaitu Rata- rata frekuensi pernafasan sebelum di lakukan terapi batuk efektif yaitu 23,37 kali per menit dengan standar deviasi 6,45, nilai minimum 8 dan maksimum 31 sedangkan bahwa rata- rata frekuensi pernafasan sesudah di lakukan terapi batuk efektif yaitu 19,81 kali per menit dengan standar devisiasi 4,17, nilai minimum 10 dan maksimal 25. Penelian kedua yaitu Dari rata-rata distribusi responden dengan efektifitas pengeluaran sputum pada pasien TB paru didapatkan a 0,05 dimana $\mathrm{P}<\mathrm{a}$ dan $\mathrm{HO}$ di tolak, yang berarti ada perbedaan jumlah sputum antara responden yang diberikan dengan batuk efektif di RSUP Persahabatan Jakarta. Penelitian ketiga yaitu dari hasil pengkajian pada pasien TB paru di RSUD Kota Kendari bahwa setelah dilakukan tindakan terapi batuk efektif terjadi perubahan kepatenan jalan nafas pada hari kedua sesi sore hari yang ditandai dengan RR Normal (24x/menit), irama nafas teratur, tidak ada ronchi.

\section{Referensi}

[1] Alpin, F. (2018). Situasi TBC Di Indoesia (Kemenkes Republik Indonesia). Diambil dari https://tbindonesia.or.id/informasi/tentang-tbc/situasi-tbc-di-indonesia-2/

[2] Anggraeni, R. N. (2019). Asuhan Keperawatan Pada Klien Dewasa TBC dengan Ketidakefektifan Bersihan Jalan Nafas di RS. Panti Waluya Sawahan Malang. (Karya Tulis Ilmiah Program Studi DIII Keperawatan STIKES Panti Waluya Malang). Diambil dari http://Repository.stikespantiwaluya.ac.id/271/

[3] Apriliani, N. A. \& Rahayu. U., (2020). Hubungan Kondisi Fisik Rumah Dengan Kejadian Penyakit TBC Paru Di Wilayah Kerja Puskesmas Momulyo Kota Surabaya. (Karya Tulis Ilmiah Program Studi DIII Keperawatan Poltekes Depkes Surabaya). Diambil dari http://journal.poltekesdepkes-sby.ac.id/index.php./KESLING/article/view/1103

[4] Anggraeni, R. N. (2019). Asuhan Keperawatan Pada Klien Dewasa TBC dengan Ketidakefektifan Bersihan Jalan Nafas di RS. Panti Waluya Sawahan Malang. (Karya Tulis Ilmiah Program Studi DIII Keperawatan STIKES Panti Waluya Malang). Diambil dari http://Repository.stikespantiwaluya.ac.id/271/

[5] Apriliani, N. A. \& Rahayu. U., (2020). Hubungan Kondisi Fisik Rumah Dengan Kejadian Penyakit TBC Paru Di Wilayah Kerja Puskesmas Momulyo Kota Surabaya. (Karya Tulis Ilmiah Program Studi DIII Keperawatan Poltekes Depkes Surabaya). Diambil dari http://journal.poltekesdepkes-sby.ac.id/index.php./KESLING/article/view/1103

[6] Arianta \& Dwi, I.M., (2018). Gambaran Asuhan Keperawatan Pemberian Prosedur Batuk Efektif Untuk Mengatasi Bersihan Jalan Nafas Tidak Efektif Pada Pasien PPOK Di Ruang Dahlia BRSU Tabanan (Diploma Thesis Jurusan Keperawatan). Diambil dari http://scholar.google.co.od/scholar?hl=id\&as-

sdt $=0 \% 2 \mathrm{C} 5 \& q=$ Konsep+Batuk+Efektif +Pada+Pasien+PPOK+dengan+Bersihan+Jalan +Nafas++Tidak+Efektif+menurut+royidi+dan+wulansari+2013\&btnG=\#d=gs_qabs\& $\mathrm{u}=\% 23 \mathrm{p} \% 3$ DlswaFQkC7p8] 
[7] Ari Setiawan, S. J. Y. N. M. (2011). Metode Penelitian Kebidanan DIII, DIV, SI,. Diambil dari https://scholar.google.co.id/scholar?hl=id\&as_sdt=0\%2C5\&q=Ari+Setiawan $\% 2 C+$ met ode+penelitian+kebidanan+DIII\%2C+DIV\%2C+s1\%2C+S2\&btnG=\#d=gs_qabs\&u= \%23p\%3DIpJYDZc1YRw]

[8] Ariyanto, J. (2018). Pengaruh Teknik Batuk Efektif Terhadap Pengeluaran Sputum Untuk Penemuan Mycobakterium Tuberculosis (MTB) Pada Pasien TB Paru Di Ruang Rajawali 6B RSUP Dr Kariadi Semarang. (Program studi S1 Keperawatan Fakultas IImu Kesehatan Universitas Muhammadiyah Semarang). Diambil dari http://repository.unimus.ac.id/1873/

[9] Faturrohman, (2020). Kasus TBC (Dinas Kesehatan Kabupaten Pekalongan). Diambil dari https://fin.co.id./2020/01/31/penyakit-tbc-masih-tinggi

[10] Hart chris, (2018). Doing a Literature Review : Releasing the Research Imagunation. Calitornia: Sage. Diambil Dari https://scholar.google.co.id/scholar?hl=id\&as_sdt=0\%2C5\&q=Hart+chris $\% 2 C+\% 282$ $018 \% 29 .+$ doing+a+literatur+review\%3A+Releasing+the\&btnG=\#d=gs_qabs\&u=\%2 3p\%3DCHWMjYOy37c]

[11] Mardiono, S. (2013). Pengaruh Latihan Batuk Efektif Terhadap Frekuensi Pernafasan Pasien TB Paru di Instalasi Rawat Inap Penyakit Dalam Rumah Sakit Pelabuhan Palembang. (Program Studi Ilmu Keperawatan STIK Bina Husada Palembang). Diambil dari

https://scholar.google.co.id/scholar?hl=id\&as_sdt=0\%2C5\&q=Mardiono\%2C+S.+\%28 2013\%29.+Pengaruh+Batuk+Efektif+terhadap+frekuensi+pernafasan+pasien+TB+p aru\&btnG=\#d=gs_qabs\&u=\%23p\%3DmY3Vlp2V9xAJ

[12] Nurarif, A. H. \& Kusuma, H., (2015). Aplikasi Asuhan Keperawatan Berdasarkan Diagnosa Medis \& NANDA Nic-Noc. Jogjakarta: Mediaction

[13] Qorisetyartha, N., dkk. (2017). Efektifitas Posisi Semi Fowler Dengan Pursed Lip Breathung Dan Semi Fowler Dengan Daphragma Breathing Terhadap SaO2 Pasien TB Paru RSP Dr. Ariowirawan Salatiga. (Program Studi S1 Ilmu Keperawatan STIKES Telogorejo Semarang). Diambil dari https://scholar.google.co.id/scholar?hl=id\&as_sdt=0\%2C5\&q=Qorisetyartha\%2C+N. $\% 2$ Cet+al+\%282017\%29.+\%22EFEKTIVITAS+POSISI+SEMI+FOWLER+DENGAN+PU RSED+LIP+BREATHING+TERHADAP+SaO2+PASIEN+TB+PARU+DI+RSP+DR.+ARIO WIRAWAN+SALATIGA. $\% 22+6 \% 281 \% 29 \& b t n G=\# d=g s \_q a b s \& u=\% 23 p \% 3 D 87 q q P w 4$ M_dc]

[14] Ridhani, A. (2016). Efektifitas Inhalasi Dengan Pemberian Posisi Semi Fowler Dan Batuk Efektif Terhadap Pengeluaran Sputum Dan Bersihan Jalan Nafas Pada Pasien TB Paru Di RSUP. Persahabatan Jakarta. (Program Studi Keperawatan Universitas 


\section{Prosiding Seminar Nasional Kesehatan 2021 Lembaga Penelitian dan Pengabdian Masyarakat Universitas Muhammadiyah Pekajangan Pekalongan}

Muhammadiyah Jakarta). Diambil dari

http://perpus.fikumj.ac.id/index.php.?p=fstream-pdf\&fid=2141\&bid=3209

[15] Rohmah, I. (2019). Dinas Kesehatan Jawa tengah data penderita TBC. Diambil dari https://jateng-tribunnews-

com.cdn.ampproject.org/v/s/jateng.tribunnews.com/amp/2019/03/28/dinkes-

perkirakan-kasus-penyakit-tbc-di-jawa-tengah-mencapai-100000-

jiwa?amp_js_v=a6\&amp_gsa=1\&usqp=mq331AQFKAGwASA $\% 3 D \#$ aoh $=16044625739$ 249\&referrer=https\%3A\%2F\%2Fwww.google.com\&amp_tf=Dari\%20\%251\%24s\&am pshare=https $\% 3 \mathrm{~A} \% 2 \mathrm{~F} \% 2 \mathrm{Fjateng}$.tribunnews.com\%2F2019\%2F03\%2F28\%2Fdinkesperkirakan-kasus-penyakit-tbc-di-jawa-tengah-mencapai-100000-jiwa

[16] Setiadi, A. (2012). Konsep \& penulisan dokumentasi Asuhan Keperawatan: Teori dan praktik. Jogjakarta: Graha IImu

[17] Tahir, R., Imalia, D. S. A., dkk. (2019). Fisioterapi Dada dan Batuk Efektif sebagai Penatalaksanaan Ketidakefektifan Bersihan Jalan Nafas pada Pasien TB Paru di RSUD Kota Kendari. (Jurusan Keperawatan Poltekes Kemenkes Kendari). Diambil dari https://scholar.google.co.id/scholar?hl=id\&as_sdt=0\%2C5\&q=Tahir\%2C+R.\%2Cet+al .$+\% 22$ Fisioterapi+dada+dan+batuk+efektif+sebagai\&btnG=\#d=gs_qabs\&u=\%23p $\%$ 3Dcb6GmMojAfY] 